\title{
A new species of Otothyropsis (Siluriformes: Loricariidae) from the rio Paraguay basin, Paraguay
}

\author{
Bárbara B. Calegari ${ }^{1}$, Pablo Lehmann A. ${ }^{2}$ and Roberto E. Reis ${ }^{1}$
}

Otothyropsis piribebuy, new species, is described from the río Piribebuy, a tributary to the río Paraguay basin, Cordillera, Paraguay. The new species is distinguished from $O$. marapoama mainly by having a continuous mid-dorsal series of 17-18 lateral plates, a robust levator crest in the hyomandibula, naked areas in the abdomen, an unpigmented circular blotch on the median portion of the lower lobe, and by several features related to sexual dimorphism. In addition, Otothyropsis is rediagnosed and its phylogenetic relationships are discussed based on its present diversity.

Otothyropsis piribebuy, espécie nueva, es descrita del río Piribebuy, cuenca del río Paraguay, Departamento de Cordillera, en Paraguay. La espécie nueva es diferenciada de O. marapoama principalmente por presentar una serie continua de 17 a 18 placas laterales médio-dorsales, cresta levator robusta en la hiomandíbula, abdomen con áreas desnudas, ausencia de pigmentación en la región media del lóbulo inferior con formato circular, y por la presencia de diversas características de dimorfismo sexual. Adicionalmente, es presentada una rediagnosis para Otothyropsis, discutida sus relaciones filogenéticas y su actual diversidad.

Key words: Cascudinho, Catfish, Neotropical, Systematics, Teleostei.

\section{Introduction}

Otothyropsis Ribeiro, Carvalho \& Melo, 2005 is a monotypic genus if Hypoptopomatinae, a loricariid subfamily that includes about 126 species (Eschemeyer \& Fong, 2011) distributed in 19 genera. The hypoptopomatine cascudinhos are small fishes with a wide distribution along the cis-Andean river drainages from Venezuela to northeastern Argentina (Schaefer, 2003). Otothyropsis and its type species $O$. marapoama were described by Ribeiro et al. (2005), who also included the species in the phylogenetic scheme of Schaefer (1998). Ribeiro et al. (2005) recovered Otothyropsis as the sister-group to the clade Pseudotothyris plus Otothyris based on the following shared characters: elongated posterior extension of the compound pterotic, which forms the dorsal margin of an augmented lateral opening of the swimbladder capsule (char. 8 of Schaefer, 1998); supraoccipital bone forming the dorsal wall of the swimbladder capsule (char. 12), and the possession of enlarged odontodes on the snout margin (char. 39). Otothyropsis marapoama, however, is distinguished from Pseudotothyris and Otothyris by having enlarged odontodes on the ventral and dorsal margins of the snout ( $v s$. enlarged odontodes only on the dorsal snout margin), by the absence of conspicuous crests of enlarged odontodes on the supraoccipital and compound pterotics in adults, and by having the abdomen completely covered by dermal plates in adults. Ribeiro et al. (2005) described Otothyropsis based on three non-exclusive autapomorphies: possession of a single median rostral plate (char. 34); possession of enlarged odontodes on the dorsal and ventral margins of the snout (char. 39), and presence of an iris operculum (char. 42).

During the last years we discovered four hypoptopomatine species, both in Brazil and Paraguay, with some degree of similarity and that partially fit the description of Otothyropsis. With the objective of testing these similarities and resolving a correct generic allocation for these species we conducted a phylogenetic re-analysis of the Hypoptopomatinae based on the data matrix of Schaefer (1998) with the modifications introduced by Ribeiro et al. (2005). Based on this re-analysis we describe one of these taxa recently collected in the rio Paraguay basin as a new species of Otothyropsis, re-diagnose the genus Otothyropsis and discuss its phylogenetic relationships.

${ }^{1}$ Laboratório de Sistemática de Vertebrados, Pontifícia Universidade Católica do Rio Grande do Sul. Av. Ipiranga 6681, P. O. Box 1429, 90619-900 Porto Alegre, RS, Brazil.barbara.calegari@gmail.com, reis@pucrs.br

${ }^{2}$ Laboratório de Ictiologia, Universidade do Vale do Rio dos Sinos. Av. Unisinos, 950, 93022-000 São Leopoldo, RS, Brazil. pablole@unisinos.br 


\section{Material and Methods}

Measurements were obtained with digital calipers under a steromicroscope on the left side of specimens. Counts of rays and dentary and premaxillary teeth were also performed under the scope. Morphometric measures were treated as percents of the standard length (SL), except for subunits of the cephalic region, treated as percents of the head length (HL). Vertebral counts consider all vertebral centra, including the five centra modified into the Weberian Apparatus and the caudal complex centrum (PU1 + U1) was counted as a single element. The osteological examination was conducted in specimens cleared and stained according to the technique proposed by Taylor \& van Dyke (1985). Dermal plate counts followed the method and terminology proposed by Schaefer (1997), and the morphometric measurements are those described by Pereira et al. (2007). Additional measurements are: pre-pelvic length (from the snout tip to the pelvic-fin origin), dorsal-fin base length (from the dorsal-fin origin to the end of the dorsal-fin base), internareal distance (horizontally between the inner margins of the posterior nares), and pre-nasal length (from the snout tip to the anterior margin of the anterior naris).

For the phylogenetic analysis we used the 46-character data matrix of Schaefer (1998) with the added characters 48 and 49 of Ribeiro et al. (2005). Thus, characters and character states mentioned in the text are those of Schaefer (1998) and Ribeiro et al. (2005), except when modifications were introduced, as described below (Table 1). The character 47 of Ribeiro et al. (2005) was excluded from our analyses because a large intraspecific variation was detected, precluding the identification of the fenestrae distribution pattern on the compound pterotic. In addition, the original codification of Ribeiro et al. (2005) for character states of Otothyropsis marapoama was changed as described below. Character 17: a subopercular plate between the opercle and the canalbearing plate is present in $O$. marapoama (state 0 ). Ribeiro et al. (2005) coded O. marapoama as absent for the subopercular plate (state 1), because they termed that plate as the canal plate 2. Character 29: the pectoral-fin spine possesses a fine serration on the median portion of its posterior margin (state 1). Character 32: the mid-dorsal series of lateral plates is truncated, ending midway between the dorsal and the caudal fin (state 1). Character 33: the median series of lateral plates is truncated posteriorly, and the last three plates of the dorsal and ventral series of lateral plates contact each other on the lateral midline anterior to the caudal fin (state 1). Character 35: rostral plate with a posterior notch on the area of articulation with the mesethmoid (state 1). Character 43: esophageal diverticulum is absent (state 0 ). Character 45: males of $O$. marapoama posses an expanded fleshy flap on the dorsal margin of the first pelvic-fin ray (state 0 ).

In addition to the characters of Schaefer (1998) and Ribeiro et al. (2005), we included the following one, numbered as character 47: extension of the sutures between neural spines. The neural spines between the dorsal-fin skeleton and the caudal fin of most hypoptopomines are sutured to each other from near the vertebral centra to approximately half the length of the neural spine (state 0 ). In the derived condition, found in Otothyropsis marapoama, O. piribebuy and the Otothyropsis sp. 3, the contiguous neural spines are sutured to each other from near the vertebral centra to or almost to their distal tips (Fig. 1; state 1). Hisonotus was found to be polymorphic to this character and was coded as missing (?).

We followed Schaefer (1998) in considering the characters 13, 24, 39, and 43 as additive. Contrary to Schaefer (1998), however, who used Neoplecostomus as the root, we rooted the trees in the compound outgroup LAH (Ancistrinae, Hypostominae, and Loricariinae of Schaefer, 1998), because we have strong evidence from Lehmann (2006) and Pereira (2008) that the Neoplecostominae represent the sister group to the Hypoptopomatinae. The phylogenetic analysis was performed with the software NONA 2.0 (Goloboff, 1999) on the Windows shell Winclada (Nixon, 1999). We used heuristic search with 1,000 replications of Random Addition Sequence (RAS) and branch swapping with Tree Bissection and Reconnection (TBR) plus a final round of TBR. Results are presented as a strict consensus tree. Institutional abbreviations include: Academy of Natural Sciences of Philadelphia, Philadelphia (ANSP); Colección Boliviana de Fauna del Museo Nacional de Historia Natural, Academia Nacional de Ciencias de Bolivia, La Paz (CBF); Coleção Zoológica de la Facultad de Ciencias Exactas y Naturales, Universidad Nacional de Asunción, Asunción (CZCEN); Laboratório de Ictiologia de Ribeirão Preto, Faculdade de Filosofia, Letras e Ciências Humanas, Universidade de São Paulo, São Paulo (LIRP); Museo de Ciencias Naturales de la UNELLEZ, Ministerio del Poder Popular para Ciencia y Tecnología, Portuguesa (MCNG); Museu de Ciências e Tecnologia, Pontifícia Universidade Católica do Rio Grande do Sul, Porto Alegre (MCP); Museu de Zoologia da Universidade de São Paulo, São Paulo (MZUSP); Departamento de Zoologia, Universidade Federal do Rio Grande do Sul, Porto Alegre(UFRGS).

Table 1. Character states of Otothyropsis species for the 49 character matrix compilation from Schaefer (1998) and Ribeiro et al. (2005).

\begin{tabular}{|c|c|c|c|c|c|}
\hline Charater & $1-10$ & $11-20$ & $21-30$ & $31-40$ & $41-49$ \\
\hline Otothyropsis marapoama & 0010100101 & 1120000100 & 0010001011 & 1111101020 & 000000100 \\
\hline Otothyropsis piribebuy & 0010100101 & 1120000100 & 0010001001 & 1111101020 & 000000100 \\
\hline Otothyropsis sp. 1 & 0010100101 & 1021000100 & 0010001001 & 1101001020 & 000000000 \\
\hline Otothyropsis sp. 2 & 0010100101 & 1120000100 & 0010001001 & 1101101020 & 000000000 \\
\hline Otothyropsis sp. 3 & 0010100101 & 1120000100 & 0010001001 & 1101101020 & 000000100 \\
\hline
\end{tabular}




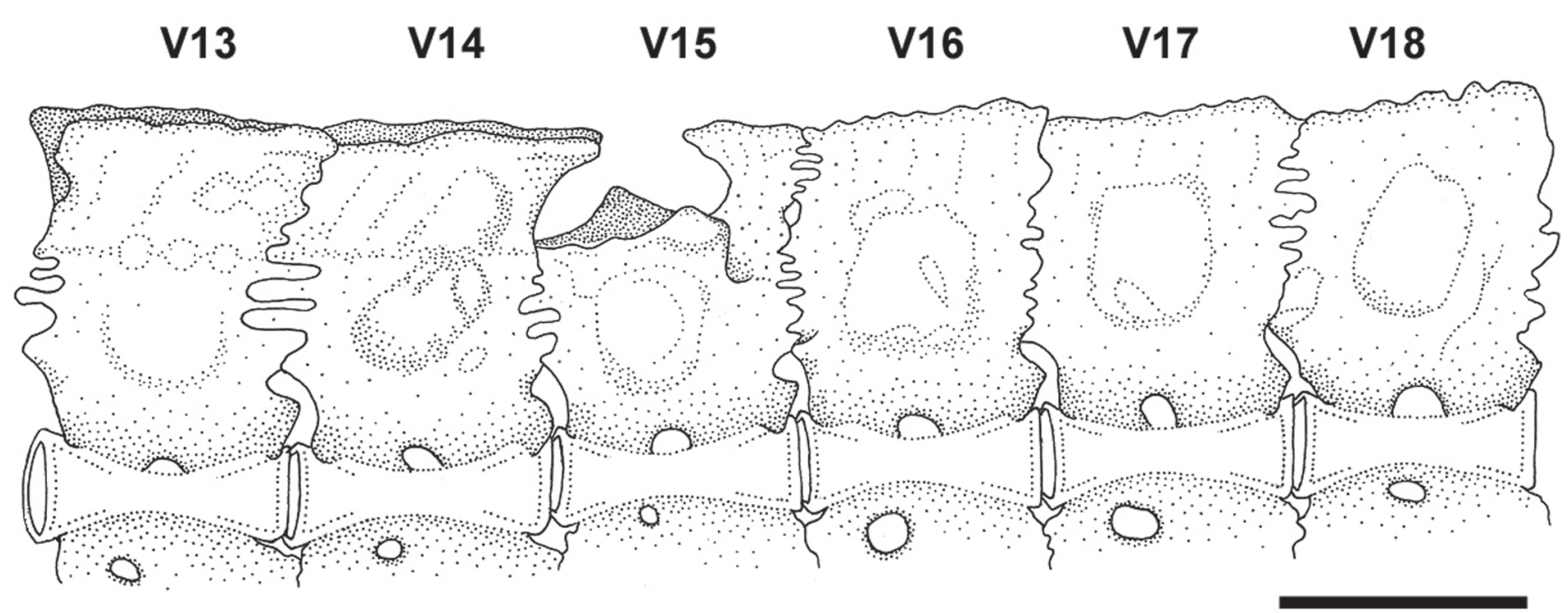

Fig. 1. Vertebral column of Otothyropsis marapoama, MCP 42119, $30.8 \mathrm{~mm}$ SL, showing the degree of sutural articulation between contiguous neural spines. Scale bar $=1 \mathrm{~mm}$.

\section{Results}

The inclusion of four additional taxa in the data matrix of Schaefer (1998) and Ribeiro et al. (2005), resulted in six maximally parsimonious trees of 118 steps $(\mathrm{CI}=0.50$ and $\mathrm{RI}=$ $0.73)$. The strict consensus tree with the intergeneric relationships is presented in Fig. 2. The phylogenetic results corroborate the inclusion of all four new species in Otothyropsis, based on a new set of diagnostic characters, as presented below.

\section{Otothyropsis Ribeiro, Carvalho \& Melo, 2005}

Otothyropsis Ribeiro, Carvalho \& Melo, 2005: 491 (Type species: O. marapoama Ribeiro, Carvalho \& Melo, 2005: 491 , by original designation).

Diagnosis. Otothyropsis is diagnosed among the Hypoptopomatinae based on the following non-exclusive synapomorphies: elongated posterior extension of the compound pterotic, which forms de dorsal margin of an augmented lateral opening of the swimbladder capsule (char. 8 , independently acquired by Otothyris and Pseudotothyris), reduced upper pharyngeal tooth plate (char. 23), and middorsal series of lateral plates truncated before the caudal fin (char. 32). In addition, Otothyropsis can be distinguished from most other members of the Otothyrini (sensu Schaefer, 1998; except Parotocinclus, Hisonotus, Epactionotus, and New Taxon 3) by the possession of a notch on the postero-dorsal region of the rostral plate (char. 35) and by having enlarged odontodes on the ventral and dorsal margins of the snout (char. 39). Otothyropsis is further differentiated from Pseudotocinclus, Eurycheilichthys, Schizolecis, Otothyris, and Pseudotothyris by the possession of a single median rostral plate (char. 34).

\section{Otothyropsis piribebuy, new species} Figs. 3-4

Undetermined genus LG2. -Evers \& Seidel, 2005: 434 (locality: Paraguay, photographs, spawning).

Holotype. CZCEN 332, $28.8 \mathrm{~mm}$ SL, female, Paraguay, Departamento Cordillera, Eusebio Ayala, rio Piribebuy a tributary to the rio Manduvira, rio Paraguay basin, $25^{\circ} 22^{\prime} 09^{\prime \prime} \mathrm{S} 56^{\circ} 58^{\prime} 20^{\prime \prime} \mathrm{W}$, 6 Jan 2008, H. S. Vera Alcaraz, J. J. Rasquin Centurion, M. C. Paradeda \& G. Solalinde.

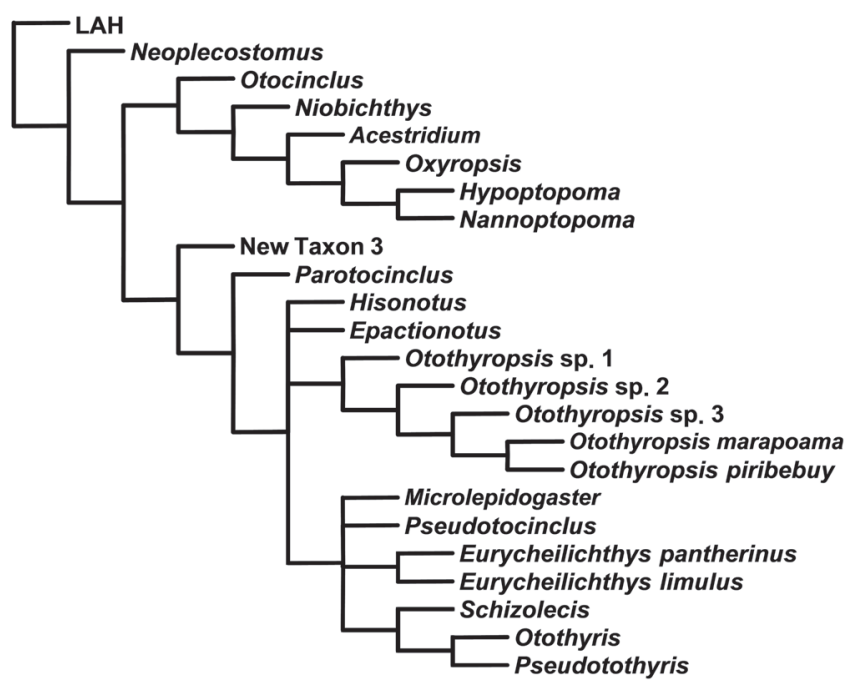

Fig. 2. Strict consensus tree depicting the phylogenetic relationships among genera of Hypoptopomatinae and species of Otothyropsis. Consensus based on six maximally parsimonious trees (primary trees with $\mathrm{L}=118 ; \mathrm{CI}=50 ; \mathrm{RI}=73$ ). Eurycheilichthys limulus represents New Taxon 1 and Epactionotus represents New Taxon 2 of the phylogeny in Schaefer (1998). 


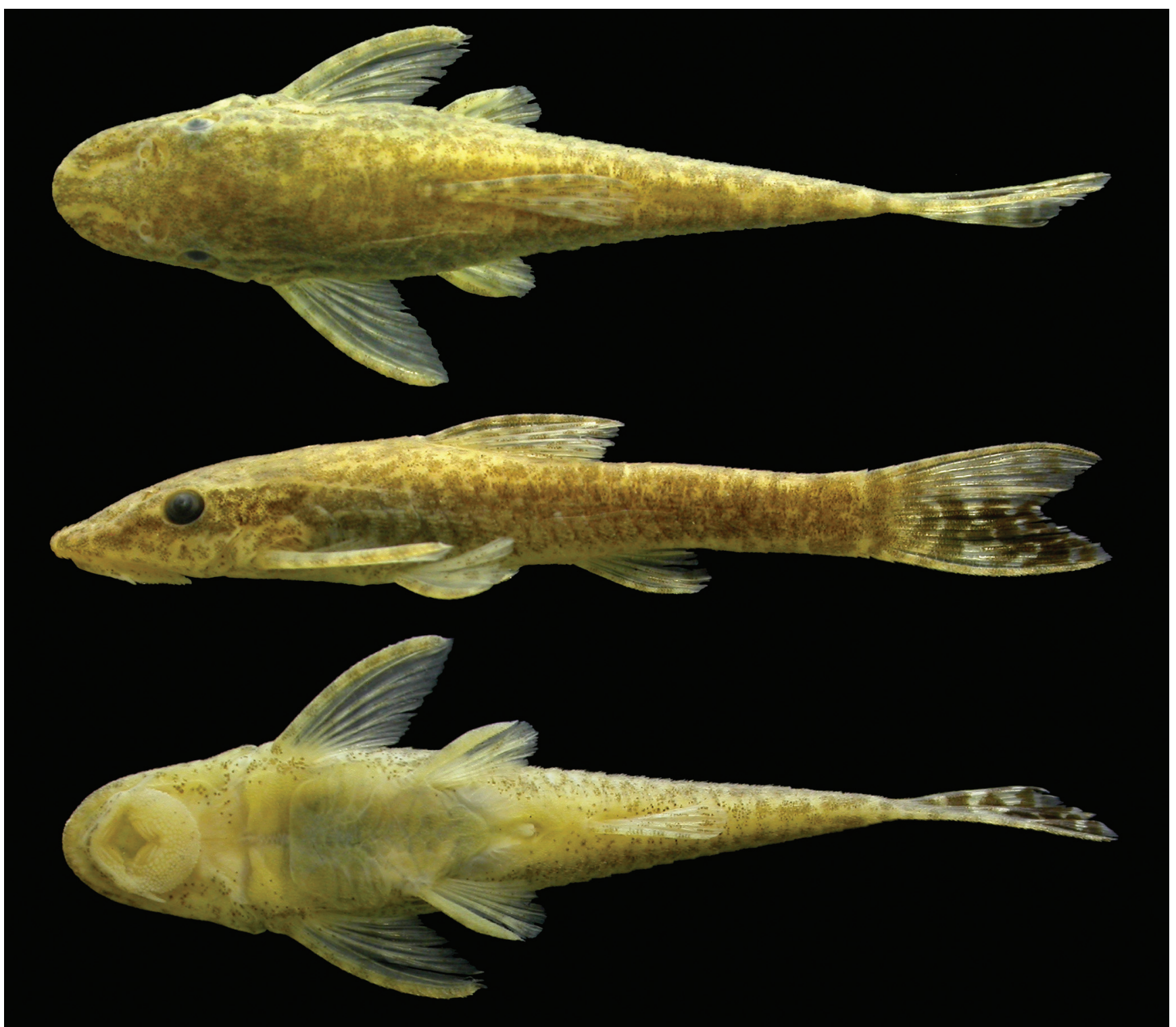

Fig. 3. Otothyropsis piribebuy, holotype, CZCEN 332, $28.8 \mathrm{~mm}$ SL, female, Paraguay, Departamento Cordillera, Eusebio Ayala, río Piribebuy a tributary to the río Manduvira, río Paraguay basin.

Paratypes. ANSP 191484, 5, 19.7-25.3 mm SL, CZCEN 333, 20, 17.3-27.2 mm SL, MCP 44394, 25, 16.7-28.3 mm SL, 3 c\&s, 17.5$27.6 \mathrm{~mm}$ SL, same data as holotype. MCP 45754, 2, 25.4-25.7 mm SL, Paraguay, Departamento San Pedro, Lima, rio Aguaray at Lima, tributary to the rio Jejui, rio Paraguay basin, 2352'35"S $56^{\circ} 29^{\prime} 01^{\prime \prime} \mathrm{W}, 27$ Dec 2007, H. S. Vera Alcaraz \& P. Britez.

Diagnosis. Otothyropsis piribebuy is diagnosed from $O$. marapoama by having the middle series of lateral plates truncated two plates before the caudal fin ( $v s$. truncated at least three plates before the caudal fin); the inner margin of the pectoral-fin spine smooth, with no serrae ( $v s$. small serration on the distal portion of the pectoral-fin inner margin); the distal margin of the accessory flange of the first ceratobranchial pointed ( $v s$. distal margin wide and rounded); the mid-dorsal lateral series with 17-18 plates and continuous, (vs. mid-dorsal lateral series with 10-11 plates and discontinuous with an intermediate gap of 3-5 plates); and the abdomen usually with unplated areas anteriorly in adults ( $v s$. abdomen entirely covered with dermal plates in adults; Fig. 5). In addition to that, males of $O$. piribebuy are distinguished from males of $O$. marapoama by their longer preanal length (63.0-66.8\% vs. 59.5-63.0\% HL) and a smaller number of middle lateral plates (19-20 vs. 21-22).

Description. Proportional measurements and counts given in Tables 2 and 3, respectively. Dorsal body profile slightly arched from snout to origin of dorsal fin.

Slightly concave and postero-ventrally oriented along dorsal-fin base, straight from terminus of dorsal-fin base to end of caudal peduncle and angling upward slightly immediately before caudal-fin origin. Ventral body profile 


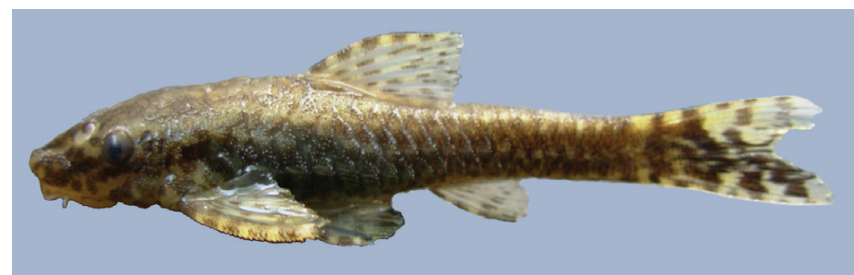

Fig. 4. Life coloration of Otothyropsis piribebuy, female paratype, MCP 44394, $28.3 \mathrm{~mm}$ SL, Paraguay, Departamento Cordillera, Eusebio Ayala, rio Piribebuy a tributary to the rio Manduvira, rio Paraguay basin. Photo by Hector Vera Alcaraz.

approximately straight, slightly ventrally oriented to pelvicfin origin and slightly postero-dorsally oriented from that point to end of anal-fin base. Greatest body depth at dorsalfin origin. Least body depth at posterior portion of caudal peduncle. Greatest body width along opercular and cleithral regions. Body progressively narrowing caudally from pelvicfin region. Caudal peduncle vertically oval in cross-section.

Head moderately broad, snout rounded in dorsal view. Region of prenasal plates between nostrils protuberant, bordered by elongate and deep depressions extending anterolaterally from each nostril to near snout tip. Eye small, dorsolaterally positioned. Iris operculum present. Dorsal margin of orbit slightly elevated. Compound pterotic perforate with middle to large size fenestrae, larger fenestrae on anteroventral portion.

Body entirely covered by dermal plates, except region around anus, region overlying lateral opening of swimbladder capsule, depression from nostril to rostral plates, area between pectoral girdle and lower lip, area around bases of paired fins, and scattered areas on anterior abdomen. Abdominal region covered with wide lateral abdominal plates laterally and with roundish to irregular, small platelets medially. Unplated areas usually present near the pectoral girdle and between lateral and medial patches of plates (Fig. 5) - one male in MCP 44394 with abdomen fully covered with plates. Ventral portions of cleithrum and coracoid completely exposed and supporting odontodes. Dorsal body surface with one slightly developed keel from posterior orbital margin to terminus of posterior extension of compound pterotic. Three transverse rows of predorsal plates, including nuchal plate. Median series of lateral plates with 19-20 plates. Lateral line with intermediate gap of 3-4 plates without sensory canal; last 3 plates without canal. Mid-dorsal series of lateral plates long and continuous, with 17-18 plates, ending 2-3 plates before the last plate in middle series. Rostral plates well developed and projected ventrally under snout margin. Odontodes on head and trunk pointed, strongly curved, uniform in size and distribution and not arranged into distinct rows. Odontodes on head not forming ridges. Odontodes on dorsal and ventral margins of snout much larger than surrounding ones. Fin rays covered by odontodes, larger on leading margin of all fins. Lips rounded and papillose, with small maxillary barbel laterally. Lower lip small, its posterior border approximately on vertical line

passing through anterior margin or middle of eye. Teeth slender, bifid, with blade-like larger medial cusp and smaller lateral cusp. Contiguous neural spines suturally articulated to each other from vertebral centrum to or almost to dorsal end in adults.

Dorsal-fin II, 7, its origin at vertical running close pelvicfin origin. Spinelet reduced, rounded and plate-like, and dorsalfin locking mechanism not functional. Adipose fin absent. Pectoral fin I,6, with posterior margin straight to slightly rounded. Tip of depressed pectoral fin extending to approximately end of pelvic-fin thickened first ray. Axillary slit of pectoral fin present, moderate in size and located below the lateral cleithral process. Pelvic fin i,5, short, with robust thickened first ray; posterior margin distinctly rounded. Tip of adpressed fin extending to anal-fin origin in males; reaching to anus in females. Adult males with fleshy flap along posterodorsal margin of thickened first pelvic-fin ray. Anal fin i,5. Caudal fin i,14,i.

Color in alcohol. Ground color of dorsal surface of head and body light to median brown, darker laterally on flanks; mostly unpigmented ventrally, except for light brown caudal peduncle and ventral portion of cheek and rostral plates. One sinuous light stripe from snout tip to each nostril, continuing as thin line through upper margin of orbit and compound pterotic. Two inconspicuous lighter stripes on each side of predorsal region and flanking dorsal fin. Fin membranes hyaline with dark brown chromatophores arranged in irregular transverse bands on rays. Caudal fin with four or five transverse bands of dark pigmentation, both on rays and membrane, stronger on base and lower lobe, sometimes imperceptible on upper. Bands on caudal-fin sometimes merging to form mostly dark lower lobe. One irregularly shaped, unpigmented area on middle of two or three lowermost branched rays usually conspicuous.

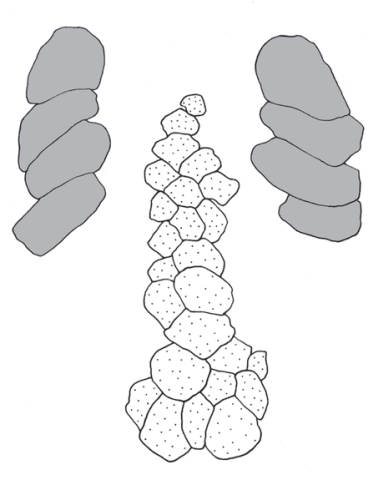

a

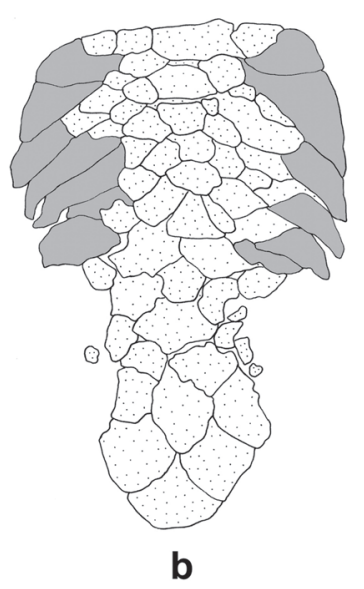

Fig. 5. Dermal plates of abdominal region of Otothyropsis. a. O. piribebuy, MCP 44394, $26.9 \mathrm{~mm}$ SL. b. O. marapoama, MCP $42119,30.8 \mathrm{~mm}$ SL. Lateral abdominal plates in gray and central abdominal plates stippled. Scale bar $=1 \mathrm{~mm}$. 
Table 2. Descriptive morphometrics of Otothyropsis species. Values are given for holotype and paratypes of O.piribebuy and O. marapoama. $\mathrm{SD}=$ Standard deviation.

\begin{tabular}{|c|c|c|c|c|c|c|c|c|c|c|c|c|c|c|c|c|c|c|}
\hline & \multicolumn{4}{|c|}{$\begin{array}{l}\text { Otothyropsis piribebuy } \\
\text { Males }(\mathrm{n}=10)\end{array}$} & \multicolumn{5}{|c|}{$\begin{array}{l}\text { Otothyropsis piribebuy } \\
\text { Females }(\mathrm{n}=9)\end{array}$} & \multicolumn{4}{|c|}{$\begin{array}{c}\text { Otothyropsis marapoama } \\
\text { Males }(\mathrm{n}=3)\end{array}$} & \multicolumn{5}{|c|}{$\begin{array}{l}\text { Otothyropsis marapoama } \\
\text { Females }(\mathrm{n}=12)\end{array}$} \\
\hline & Low & High & Mean & $\mathrm{SD}$ & Holotype & Low & High & Mean & $\mathrm{SD}$ & Low & High & Mean & $\mathrm{SD}$ & Holotype & Low & High & Mean & $\mathrm{SD}$ \\
\hline Standard length $(\mathrm{mm})$ & 22.3 & 24.9 & 23.4 & - & $\begin{array}{l}28.8 \\
\text { Percent }\end{array}$ & $\begin{array}{l}22.5 \\
\text { ts of S }\end{array}$ & $\begin{array}{l}28.8 \\
\text { tandal }\end{array}$ & $\begin{aligned} & 26.6 \\
& \text { d leng }\end{aligned}$ & - & 20.7 & 26.7 & 24.0 & - & 37.4 & 20.8 & 37.4 & 26.4 & \\
\hline Head length & 33.6 & 37.8 & 36.8 & 1.2 & 35.0 & 33.4 & 37.7 & 36.1 & 1.4 & 32.7 & 37.8 & 35.9 & 2.8 & 34.1 & 34.1 & 39.7 & 37.2 & 1.8 \\
\hline Predorsal length & 47.1 & 50.5 & 48.8 & 1.0 & 47.6 & 46.5 & 50.1 & 48.6 & 1.4 & 47.1 & 48.9 & 48.1 & 0.9 & 47.8 & 45.7 & 50.1 & 48.3 & 1.5 \\
\hline Postdorsal length & 38.8 & 42.3 & 40.4 & 1.1 & 40.3 & 39.4 & 42.5 & 40.9 & 1.3 & 39.3 & 43.8 & 41.2 & 2.3 & 39.5 & 39.0 & 45.7 & 41.5 & 2.1 \\
\hline Preanal ler & 63.0 & 66.8 & 65.0 & 1.0 & 64.4 & 63.2 & 67.4 & 65.6 & 1.5 & 59.5 & 63.0 & 61.4 & 1.7 & 63.9 & 60.9 & 66.1 & 63.4 & 1.5 \\
\hline Prepe & 42.2 & 46.3 & 44.2 & 1.2 & 43.4 & 43.2 & 46.3 & 44.6 & 1.1 & 41.2 & 43.8 & 42.4 & 1.3 & 40.8 & 40.6 & 45.4 & 43.5 & 1.5 \\
\hline Cleit & 22.5 & 25.4 & 24.4 & 0.9 & 23.8 & 23.8 & 26.7 & 25.2 & 0.9 & 24.4 & 25.1 & 24.7 & 0.3 & 24.7 & 23.8 & 25.8 & 24.8 & 0.6 \\
\hline Tho & 17.2 & 19.3 & 18.2 & 0.6 & 17.1 & 17.1 & 19.7 & 18.6 & 0.9 & 15.6 & 21.2 & 18.2 & 2.8 & 17.0 & 15.9 & 18.4 & 17.2 & 0.7 \\
\hline Abd & 20.8 & 23.1 & 21.8 & 0.8 & 22.4 & 20.8 & 24.3 & 22.4 & 1.0 & 20.1 & 20.7 & 20.4 & 0.3 & 25.3 & 18.3 & 25.3 & 21.0 & 1.8 \\
\hline & 25.4 & 29.8 & 27.4 & 1.2 & 4.8 & 24.8 & 29.1 & 26.9 & 1.3 & 24.3 & 3 & 25.4 & $1 .($ & 26.0 & 24.2 & 7 & 26.0 & 2 \\
\hline Dor & 12.2 & 14.7 & 13.6 & 0.8 & 3.2 & 12.9 & 14.7 & 13.8 & 0.6 & 10.8 & & 13.1 & 2.0 & 13.7 & 11.0 & 14.7 & 12.9 & 1.0 \\
\hline Pec & 26.7 & 30.4 & 28.1 & 1.0 & 24.9 & 24.9 & 29.9 & 28.2 & 1.5 & 26.1 & 4 & 26.8 & 0.6 & 25.2 & 25.2 & 30.5 & 27.8 & 1.7 \\
\hline Pel & 16.8 & 19.7 & 18 & 1.0 & .0 & 13.7 & 17.3 & 15.5 & 1.1 & 16.4 & & 17.8 & 1. & 14 & 14.5 & & 15.9 & 0.9 \\
\hline Ana & 16.1 & 19.3 & 17.5 & 1.1 & 6 & 14.8 & 19.6 & 16.7 & 1.7 & 17.7 & 18 & 18.0 & 0. & 15.1 & 15.1 & 19.8 & 17.3 & 1.2 \\
\hline $\mathrm{Cau}$ & 28.7 & 32.3 & 30.4 & 1.2 & 30.0 & 28.1 & 31.3 & 30.3 & 1.2 & 28.9 & 3 & 30.2 & 1. & 29.5 & 28.4 & 35.9 & 30.9 & 2.1 \\
\hline $\mathrm{Cau}$ & 10.3 & 11.5 & 10.8 & 0.4 & 10.1 & 9.7 & 11.0 & 10.3 & 0.4 & 10.0 & 10.7 & 10.3 & 0. & 9. & 9.3 & 11.0 & 9.8 & 0.5 \\
\hline Cauda & 6.7 & 7.4 & 7.1 & 0.2 & 6 & 5.9 & 7.2 & 6.6 & 0.4 & 4.7 & 7. & 5.8 & 1.3 & 6. & 4.4 & 6.9 & 5.7 & 0.7 \\
\hline Body & 15.0 & 18.3 & 16.9 & 1.1 & 15.8 & 15.8 & 19.2 & 17.1 & 1.1 & 15.8 & 18.3 & 17.1 & 1.3 & 17.5 & 15.0 & 18.7 & 16.9 & 1.0 \\
\hline Bod & 16.2 & 19.8 & 8.9 & 1.0 & $\begin{array}{c}19.5 \\
\text { Perc }\end{array}$ & $\begin{array}{l}19.5 \\
\text { nts of }\end{array}$ & 22.7 & $\begin{array}{l}21.0 \\
\text { lengtl }\end{array}$ & 0.9 & 17.9 & 9.6 & 18.7 & 0.9 & J & 16.9 & 23.8 & 20.4 & 2.1 \\
\hline Heac & 42.2 & 52.1 & 46.3 & 3.0 & 45.7 & 41.4 & 48.1 & 45.4 & 2.4 & 44.1 & 51.7 & 47.4 & 3.9 & 45.8 & 42.0 & 52.8 & 45.1 & 3.4 \\
\hline Snout & 47.3 & 50.4 & 48.5 & 1.0 & 50.2 & 47.1 & 53.2 & 50.2 & 1.8 & 44.5 & 50.5 & 47.7 & 3.0 & 48.4 & 47.4 & 50.5 & 48.7 & 1.0 \\
\hline diameter & 14.0 & 15.1 & 14.4 & 0.3 & 12.3 & 12.3 & 14.1 & 13.1 & 0.6 & 13.6 & 14.4 & 13.9 & 0.4 & 12.3 & 11.3 & 16.0 & 13.1 & 1.2 \\
\hline Intero & 38.8 & 45.8 & 42.3 & 2.1 & 40.9 & 38.4 & 44.0 & 41.2 & 2.0 & 37.3 & 43.4 & 39.5 & 3.3 & 44.7 & 35.9 & 44.7 & 39.1 & 3.1 \\
\hline Intern & 6.3 & 10.2 & 8.7 & 1.1 & 14.4 & 12.3 & 15.9 & 13.9 & 1.0 & 10.2 & 13.0 & 11.5 & 1.4 & 12.4 & 10.7 & 13.5 & 12.3 & 0.9 \\
\hline Prena & 28.9 & 32.9 & 30.5 & 1.2 & 35.8 & 31.6 & 36.4 & 34.4 & 1.5 & 28.4 & 33.2 & 31.2 & 2.5 & 30.4 & 29.7 & 34.1 & 31.7 & 1.2 \\
\hline Barbel length & 8.1 & 10.9 & 9.9 & 0.8 & 9.2 & 6.4 & 10.6 & 8.9 & 1.3 & 6.2 & 15.2 & 11.7 & 4.8 & 9.2 & 4.9 & 17.0 & 10.2 & 3.4 \\
\hline
\end{tabular}

Sexual dimorphism. Secondary sexual dimorphism in hypoptopomines is primarily characterized by the possession by males of an urogenital papilla, located immediately posterior to the anus, which is absent in females. Adult males also posses a fleshy flap along the dorsal margin of the thickened first pelvic-fin ray in most species, which is also absent in females. Otothyropsis piribebuy shares the two sexually dimorphic features above, and in addition has a longer first pelvic-fin ray, reaching to the origin of the anal fin ( $v s$. shorter, never reaching to that point in females). Furthermore, $O$. piribebuy displays a remarkable secondary sexual dimorphism in the size of the naris opening, which is much bigger in males and affects most proportions of the head. Males have a smaller internareal distance (6.3-10.2 vs. 12.3-15.9\% HL in females; Fig. 6), smaller prenasal length (28.9-32.9 vs. 31.6-36.4\% $\mathrm{HL}$ in females), and larger orbital diameter (12.3-14.1 vs. 14.0-15.1\%
HL in females). Males also have a narrower body at the level of the dorsal-fin origin (16.2-19.8vs. 19.5-22.7\% SL in females).

Distribution and habitat. Otothyropsis piribebuy is known from two localities on the left tributaries to the río Paraguay, the río Piribebuy near Eusébio Ayala, Cordillera and the río Aguaray near Lima, San Pedro, Paraguay (Fig. 7). In both localities the fishes were collected on marginal vegetation, mainly formed by hanging grasses in the former and floating water-hyacinths (Eichornia) is the later.

Etymology. Otothyropsis piribebuy is named after the rio Piribebuy, rio Paraguay basin, where most type specimens were collected. In the native Guarany language "Piri vevui" means gentle breeze, a sensation caused by the many cool rivers in the region. A noun in apposition.

Table 3. Frequency of distribution of meristic data for Otothyropsis piribebuy. Holotype values are marked with an asterisk. Meristic maked with double asterisks was counted in c\&s specimens only. $\mathrm{N}=$ Number of specimens.

\begin{tabular}{lccc}
\hline Character & $\mathrm{N}$ & Range & Distribution Frequency \\
\hline Teeth in left premaxilla & 19 & $10-19$ & $10(1), 13(1), 15(3), 16(8), 17(3), 18(1), 19(2)^{*}$ \\
Teeth in right premaxilla & 19 & $13-19$ & $13(2), 15(4), 16(2), 17(6), 18(2), 19(1), 20(2)^{*}$ \\
Teeth in left dentary & 19 & $12-18$ & $12(1), 13(2), 14(6), 15(4)^{*}, 16(4), 17(1), 18(1)$ \\
Teeth in right dentary & 19 & $13-18$ & $13(2), 14(2), 15(8), 16(2), 17(3)^{*}, 18(2)$ \\
Plates in median lateral series & 19 & $19-20$ & $19(11), 20(8)^{*}$ \\
Plates between anal and caudal fin & 19 & $9-10$ & $9(4), 10(15)^{*}$ \\
Plates at dorsal-fin base & 19 & $4-6$ & $4(1), 5(17)^{*}, 6(1)$ \\
Plates at anal-fin base & 19 & $3-4$ & $3(17)^{*}, 4(2)$ \\
Predorsal plates & 19 & 3 & $3(19)^{*}$ \\
Total vertebrae** & 3 & $26-27$ & $26(2), 27(1)$ \\
\hline
\end{tabular}




\section{Discussion}

According to the phylogenetic analysis of Ribeiro et al. (2005), Otothyropsis is sister to a clade formed by Pseudotothyris plus Otothyris, based on the elongation of the posterior region of the compound pterotic, which forms the lateral wall of the swimbladder capsule (char. 8), on the involvement of the supraoccipital in forming the dorsal wall of the swimbladder capsule (char. 12), and by having hyperthrophied odontodes on the snout margin (char. 39). With the addition of four other Otothyropsis species in the data matrix, however, these characters were recovered at different levels within the phylogeny, and do not support the above relationships. Our results suggest that the character 8 evolved independently in Otothyropsis and in the clade formed by Pseudotothyris plus Otothyris. Similarly, character 12 evolved independently in a subclade within Otothyropsis and in the Pseudotothyris plus Otothyris clade. Finally, character 39 was optimized as a synapomorphy for the entire subfamily (hyperthrophied odontodes ventrally and dorsally on the snout margin, state 2) with a reversal to state 1 (hyperthrophied odontodes on dorsal margin only) in Pseudotothyris plus Otothyris, thus corroborating the findings of Schaefer (1998).

Despite our analyses did not recover an exact resolution for the relationships of Otothyropsis among the remaining Otothyrini, Otothyropsis itself was recovered as a monophyletic group with five species. Otothyropsis piribebuy and $O$. marapoama are more closely related to each other by sharing the middle series of lateral plates truncated posteriorly (char. 33, state 1), and are the sister-group to Otothyropsis sp. 3 by sharing the neural spines sutured to or almost to the dorsal end in adults (char. 47, state 1; Fig. 1). The clade formed by these three species and Otothyropsis sp. 2 is supported by the supraoccipital taking part of the dorsal wall of the swimbladder capsule (char. 12, state 1). Otothyropsis sp. 1 is the most basal species in the genus.

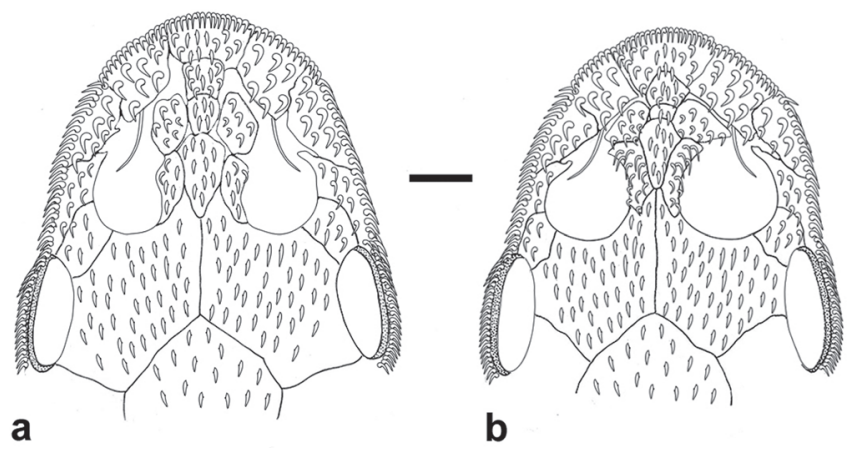

Fig. 6. Otothyropsis piribebuy, sexual dimorphism in the size of the nostrils. a. Female, paratype, MCP 44394, $24.4 \mathrm{~mm} \mathrm{SL}$. b. Male, paratype, MCP 44394, $26.9 \mathrm{~mm}$ SL. Scale bar $=1 \mathrm{~mm}$.
Comparative material. LORICARIINAE: Rineloricaria strigilata: MCP 19643 (17+ 1 c\&s), Brazil, Rio Grande do Sul, Encruzilhada do Sul, arroio Abrânio, tributary to rio Camaquã or road from Encruzilhada do Sul to Canguçu, $41.3 \mathrm{~km}$ from Encruzilhada do Sul. NEOPLECOSTOMINAE: Neoplecostomus microps: MCP 12199 $(19+2$ c\&s), Brazil, São Paulo, Monteiro Lobato, tributary to rio Buquira at bridge of road SP-150, rio Paraíba do Sul drainage. HYPOPTOPOMATINAE: Acestridium discus: MZUSP 85320 (7 + 1 c\&s), Brazil, Amazonas, Rio Preto da Eva, igarapé Barroso at bridge of road Francisca Mendes. Epactionotus bilineatus: MCP 29293 (29 + 3 c\&s), Brazil, Rio Grande do Sul, Itati, arroio das Bananeiras, tributary to rio Três Forquilhas. UFRGS $4491(18+2$ c\&s), Brazil, Rio Grande do Sul, Maquiné, rio Maquiné and arroio do Ouro, between Maquiné and Barra do Ouro. Eurycheilichthys limulus: MCP $22700(48+2 \mathrm{c \& s})$, rio Passo Novo on road from Cruz Alta to Ibirubá, rio Jacuí basin. Eurycheilichthys pantherinus: MCP 35042 (17 + 3 c\&s), Brazil, Rio Grande do Sul, Bom Jesus, rio dos Touros on road from Rondinha to Silveira. Hisonotus armatus: MCP 25458 (7 + 3 c\&s), Brazil, Rio Grande do Sul, Agudo, arroio Corupá on road between Agudo and the Dona Francisca power plant. Hisonotus nigricauda: MCP $26865(89+3$ c\&s), Brazil, Rio Grande do Sul, Rosário do Sul, arroio do Salso on road BR-158, tributary to rio Ibicuí da Armada. Hisonotus notatus: MCP 18098 (189 + 4 c\&s), Brazil, Espírito Santo, São José das Torres, rio São José das Torres on highway BR-101, between São José das Torres and Travessão. Hypoptopoma inexspectatum: MCP 15744 (24 + 2 c\&s), Brazil, Mato Grosso, Cáceres, rio Paraguay at Cáceres. Microlepidogaster perforatus: MCP 17717 (4 + 1 c\&s) and ANSP 174718 ( 1 c\&s), Brazil, Minas Gerais, Carandaí, rio Carandaí, tributary to rio Grande upstream town of Carandaí. Nannoptopoma spectabilis: MCNG 26579 (2 c\&s), Venezuela, rio Orinoco basin. Niobichthys ferrarisi: MCP 34810 (2+1 c\&s), Venezuela, Amazonas, rio Bária $200 \mathrm{~m}$ upstream from Base Neblina camp. Otocinclus vestitus: CBF 3945 (1 c\&s), Bolívia, Pando, Nicolas Suarez, creek on right margin of rio Nareuda, ca. $5 \mathrm{~km}$ from mouth of rio Tahuamanu. Otocinclus xakriaba: MCP 16879 (21+4 c\&s), Brazil, Minas Gerais, Januaria, rio Peru-Açu at Fabião. Otothyris travassosi: MCP 18105 (30+2 c\&s), Brazil, Espírito Santo, Boa

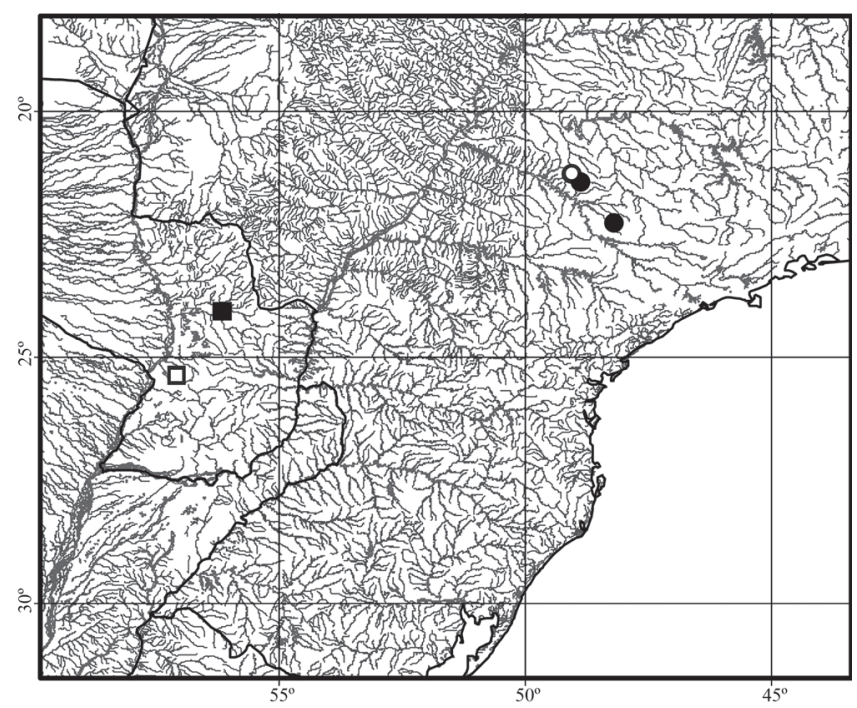

Fig. 7. Geographic distribution of Otothyropsis marapoama (dots) and $O$. piribebuy (squares). Open symbols for type localities. 
Esperança, rio Braço Norte, tributary to rio São Mateus on road ES-130. Otothyropsis sp. 1: MCP 39531 (3+2 c\&s), Brazil, Santa Catarina, Canoinhas, rio Água Verde, tributary to rio Canoinhas. UFRGS 11498 (14 + 2 c\&s), Brazil, Santa Catarina, Monte Castelo, creek tributary to rio Negro basin on highway BR-116. Otothyropsis sp. 2: MCP 45755 (1+1 c\&s), Brazil, Paraná, Telêmaco Borba, creek tributary to middle rio Tibaji. UFRGS 11495 (6 + 1 c\&s), Brazil Paraná, Uvaia, rio Tabagi $100 \mathrm{~m}$ from road BR-373. Otothyropsis sp. 3: MCP 45756 (4+1 c\&s), Brazil, Mato Grosso do Sul, Ribas do Rio Pardo, rio Verde at mouth of ribeirão Tamanduá. Otothyropsis marapoama: LIRP 5640, holotype, and LIRP 4621 ( 2 of 3 paratypes), Brazil, São Paulo, Marapoama, ribeirão Cubatão. LIRP 5641 (3 of 48 paratypes), MZUSP 87893 (3 + 1 c\&s) paratypes), and MCP 38303 (9+1 c\&s paratypes), Brazil, São Paulo, Catanduva, córrego Cubatão tributary to rio Tietê at Cubatão farm. MCP 42119 (1 c\&s), Brazil, São Paulo, Gavião Peixoto, rio Boa Esperança, tributary to left margin of rio Jacaré-Guaçu near its mouth. Oxyropsis wrightiana: MCP 34503 (27 + 3 c\&s), Peru, Loreto, rio Pacaya, cocha Tamara. Parotocinclus cesarpintoi: MCP 30562 (9+2 c\&s), Brazil, Pernambuco, Primavera, rio Ipojuca near mouth of rio do Brejo at village Vila dos Pilões. Parotocinclus collinsae: ANSP 175923 (1+1 c\&s), Guiana, Siparuni VIII-2, dark water stream 5 min downstream from Burro Burro camp site. Parotocinclus doceanus: MCP 18084 (14+4 c\&s), Brazil, Minas Gerais, Mayrink, rio Mucuri ca. $16 \mathrm{~km} \mathrm{~W}$ of Manuque and $0.5 \mathrm{~km}$ upstream from bridge on road BR-418, km 39. Parotocinclus maculicauda: MCP 29086 (17 + 2 c\&s), Brazil, Santa Catarina, Itajaí, creek tributary to rio do Meio ca. $5 \mathrm{~km}$ from road BR-486 towards Rio do Meio. Pseudotocinclus juquiae: MZUSP 79048 (2 paratypes) and MCP 45129 (3 + 2 c\&s), Brazil, São Paulo, Juquitiba, creek on Estio farm, on road from Santa Rita to Juquitiba ca. $8 \mathrm{~km}$ S of Santa Rita. Pseudotocinclus parahybae: MZUSP 83611 (1 paratype), MZUSP 47581 (1 c\&s paratype), and MCP 45094 (6 + 2 c\&s), Brazil, São Paulo, Pindamonhangaba, creek tributary to Ribeirão Grande on São Sebastião do Ribeirão Grande farm. Pseudotocinclus tietensis: MCP 20090 (2 + 1 c\&s), Brazil, São Paulo, Salesópolis, riacho Paraitinguinha on road from Salesópolis to Jacareí. Pseudotothyris obtusa: MCP 31728 (7+ 2 c\&s), Brazil, São Paulo, Itanhaém, creek tributary to rio Preto $c a .2 \mathrm{~km}$ from state airport. Schizolecis guntheri: MCP 31558 (100+ 3 c\&s), Brazil, Rio de Janeiro, Parati, rio São Roque on highway BR-101 near to Tarituba.

\section{Acknowledgements}

We are grateful to Héctor Vera for making available to us the specimens used to describe this new species and for the photograph in Fig. 4. We thank F. Jerep and T. Carvalho for their comments, criticism, and the help in taking photographs. We are also grateful to M. A. Timmens for preparing illustrations of Figs. 1, 5, and 6, and to I. Franz for preparing the map of Fig. 7. We thank D. Taphorn (MCNG), F. A. Bockmann (LIRP), L. R. Malabarba (UFRGS), M. Sabaj-Peres (ANSP), O. Oyakawa (MZUSP), S. Barrera (CBF), and U. Schultz (UNISINOS) for loaning or donating specimens for our study. This study was supported by fellowships from the Conselho Nacional de Desenvolvimento Científico e Tecnológico (processes CNPq 134901/2008-8 to BBC and 303362/2007-3 to RER).

\section{Literature Cited}

Eschmeyer, W. N. \&. J. D. Fong. 2011. Species of fishes by family/ subfamily. http://research.calacademy.org/research/ichthyology/ catalog/speciesbyfamily.asp. Accessed on May 25, 2011.

Evers, H.-G. \& I. Seidel. 2005. Catfish atlas. Mergus, Melle, Germany, 942p.

Gauger, M. F. W. \& P. A. Buckup. 2005. Two new species of Hypoptopomatinae from the rio Paraíba do Sul basin, with comments on the monophyly of Parotocinclus and the Otothyrini (Siluriformes: Loricariidae). Neotropical Ichthyology, 3: 509-518.

Goloboff, P. A., J. S. Farris \& K. C. Nixon. 2008. TNT, a free program for phylogenetic analysis. Cladistics, 24: 774-786.

Lehmann, P. A. 2006. Anatomia e relações filogenéticas da família Loricariidae (Ostariophysi: Siluriformes) com ênfase na subfamília Hypoptopomatinae. Unpublished Ph.D. Dissertation. Porto Alegre, PUCRS, 420p.

Pereira, E. H. L. 2008. Relações filogenéticas de Neoplecostominae Regan (1904) (Siluriformes: Loricariidae). Unpublished Ph.D. Dissertation. Porto Alegre, PUCRS, 414p.

Pereira, E. H. L., F. Vieira \& R. E. Reis. 2007. A new species of sexually dimorphic Pareiorhaphis Miranda Ribeiro, 1918 (Siluriformes: Loricariidae) from the rio Doce basin, Brazil. Neotropical Ichthyology, 5: 443-448.

Ribeiro, A. C., M. Carvalho \& A. L. A. Melo. 2005. Description and relationships of Otothyropsis marapoama, a new genus and species of Hypoptopomatinae catfish (Siluriformes: Loricariidae) from rio Tietê basin, southeastern Brazil. Neotropical Ichthyology, 3: 489-498.

Schaefer, S. A. 1997. The neotropical cascudinhos: Systematics and biogeography of the Otocinclus catfishes (Siluriformes: Loricariidae). Proceedings of the Academy of Natural Sciences of Philadelphia, 148: 1-120.

Schaefer, S. A. 1998. Conflict and resolution: impact of new taxa on phylogenetic studies of the neotropical cascudinhos (Siluroidei: Loricariidae). Pp. 375-400. In. Malabarba, L. R., R. E. Reis, R. P. Vari, Z. M. S. Lucena \& C. A. S. Lucena (Eds.). Phylogeny and Classification of Neotropical Fishes. Porto Alegre, Edipucrs, $603 \mathrm{p}$.

Schaefer, S. A. 2003. Hypoptopomatinae. Pp. 321-329. In: Reis, R. E., S. O. Kullander \& C. J. Ferraris, Jr. (Eds.). Checklist of the Freshwater Fishes of South and Central America. Porto Alegre, Edipucrs, 729p.

Taylor, W. R. \& G. C. van Dyke. 1985. Revised procedures for staining and clearing small fishes and other vertebrates for bone and cartilage study. Cybium, 9: 107-119.

Accepted January 25, 2011 Published June 30, 2011 